\title{
De Maastrichtse onderwijs benadering
}

Citation for published version (APA):

Scherpbier, A. J. J. A. (2000). De Maastrichtse onderwijs benadering. Maastricht University. https://doi.org/10.26481/spe.20000218as

Document status and date:

Published: 18/02/2000

DOI:

10.26481/spe.20000218as

Document Version:

Publisher's PDF, also known as Version of record

\section{Please check the document version of this publication:}

- A submitted manuscript is the version of the article upon submission and before peer-review. There can be important differences between the submitted version and the official published version of record.

People interested in the research are advised to contact the author for the final version of the publication, or visit the DOI to the publisher's website.

- The final author version and the galley proof are versions of the publication after peer review.

- The final published version features the final layout of the paper including the volume, issue and page numbers.

Link to publication

\footnotetext{
General rights rights.

- You may freely distribute the URL identifying the publication in the public portal. please follow below link for the End User Agreement:

www.umlib.nl/taverne-license

Take down policy

If you believe that this document breaches copyright please contact us at:

repository@maastrichtuniversity.nl

providing details and we will investigate your claim.
}

Copyright and moral rights for the publications made accessible in the public portal are retained by the authors and/or other copyright owners and it is a condition of accessing publications that users recognise and abide by the legal requirements associated with these

- Users may download and print one copy of any publication from the public portal for the purpose of private study or research.

- You may not further distribute the material or use it for any profit-making activity or commercial gain

If the publication is distributed under the terms of Article $25 \mathrm{fa}$ of the Dutch Copyright Act, indicated by the "Taverne" license above, 


\section{DE}

MAASTRICHTSE

ONDERWIJS

BENADERING

AllA Scherpbier 
O AJIA Scherplxier, Mastrich 2000

ISBN $905278275 x$

Universitaire Pers Malastricht

Voringeving en druk: Datawyse bv Madtricht 


\section{$\mathrm{DE}$ \\ MAASTRICHTSE \\ ONDERWIJS \\ BENADERING}

Rede in verkorte vorm uitgesproken bij de aanvaarding van het ambt van hoogleraar in de kwaliteitsbevordering van het medisch onderwijs aan de Universiteit Maastricht op vrijdag 18 februari 2000 door

Dr AlJA Scherpbier 



\section{GEACHTE RECTOR, DAMES EN HEREN,}

De komende drie kwartier ga ik u iets vertellen over de Maastrichtse Onderwijs Benadering. De inhoud van dit verhaal heb ik niet in mijn eentje bedacht. Het is de resultante van veel gesprekken met studenten en collegae, van de voorbereiding voor voordrachten en van gezamen. lijk onderzoek. Kortom, van twintig jaar samenwerken in medisch onderwijs. Deze voordracht houd ik dan ook namens vele anderen.

De voordracht heeft twee beperkingen. Het gaat alleen over medisch onderwijs, want daar weet ik iets over. Van ander onderwijs weet ik niet zoveel. De tweede beperking is dat $u$ vandaag geen p.r-verhalen te horen krijgt, want daar is niet veel van te leren. Mijns inziens moeten wij open en eerlijk over onze problemen in het onderwijs praten. ${ }^{1}$

De voordracht bestaat uit drie onderdelen. Eerst zal ik ingaan op de kwaliteiten van het medisch onderwijs in Maastricht, orn te onderzoeken of er verbeteringen mogelijk zijn. Daarna zal ik het nieuwe curriculum presenteren dat door de curriculumherzieningscommissie ontwikkeld wordt. Ik zal u de grote lijn ervan uitleggen, omdat voor gedetailleerde invulling nog overleg moet plaatsvinden met de capaciteitsgroepen, het academisch ziekenhuis en de geaffilieerde ziekenhuizen. Voor het oplossen van onze problemen en het opstarten en onderhouden van een nieuw curriculum is de Maastrichtse Onderwijs Benadering van belang, die dus op verschillende platsen in de voordracht aan de orde komt en die ik tot slot zal samenvatten. 
Het medisch onderwijs in Maastricht had en heet in zin algemeenheid een goede pers. Dat is de verdienste van studenten en docenten die zich ingespannen hebben woor goed onderwijs. Het is zeker geen reden om zelfgenoegzaam achterover te leunen. Als we de goede pers willen houden, moeten we nagaan wat er werbeterd moet en kan worden. Een aantal gegevens uit programma-evaluaties en onderzoeksbevindingen die aanknopingspunten voor verbeteringen bieden, ga ik bespreken. De goede pers wordt deels bepaald door externe beoordelingen. De vraag is hoe moeten we deze beoordelingen eigenlijk interpreteren? Daarna ga $i k$ in op recente inzichten uit de cognitieve psychologie om na te gaan of de inhoud en opbouw van onze opleiding aan deze inzichten voldoen.

\section{PROGRAMMA-EVALUATIE}

In de faculteit geneeskunde van Maastricht wordi het onderwijsprogramma uifgebreid geëvalueerd. ${ }^{2}$ Onderwijsprogramma's en docenten worden in het algemeen heel positiet beoordeeld. De gegevens worden gerapponteend aan de coördinatoren en de planningsgroep van het betreffende ondlerwijs en aan de individuele docenten en hum capaciteitsgroepvoorzitters. Het is uiteraard de bedoeling dat de gegevens gebruikt worden om de kwaliteit te verbeteren. Er is altijd van uitgegaan dat alle betrokkenen daarin hun eigen verantwoordelijkheid zouden nemen. Om dit proces te stimuleren worden de gegevens ook besproken in onderwijsoverlegorganen en in gesprekken met capaciteitsgroepvoorzitters. In de praktijk blijkt helaas dat deze eigen verantwoordelijkheid niet door iedereen zo ervaren wordt.

Een paar woorbeelden om de problematiek te illustreren. De tutoren in de onderwijsgroep hebben een centrale positie in ons onderwijssysteem. In het studiejaar 1998-1999 behaalden 41 van de 542 tutoren $(8 \%)$ een onvoldoende. ${ }^{4}$ Bij madere analyse waren er gelukkig maar twee recidivisten, mar toch is 41 te veel. Hierbij zijn alleen de tutoren meegeteld over wie voldoende studentenoordelen beschikbar waren. In hel lopende studiejaar zijn er in de eerste drie blokken al 31 onvol doendes $(11 \%)$ loegekend. 
Een ander probleem is dat een alantal tutoren vaak weg is en zich laat vervangen door al dan niet verschillende collega's, die niets van het blok weten.

Deze gegevens kunnen op verschillende manienen gehterpreteerd worden. Gezien het grote aantal tutoren, zou gesteld kunnen worden dat het meevalt. Het is wellicht een illusie on te verwachten dat alke tutor even goed kan functioneren. Een andere verklaring is dat de tutorrol veel moeilijker is dan wij altijd dachten. Met name bij onderwijsgroepen die niet goed functioneren. wordt veel gevergd van de tutor. Wit onderzoek blijkt dat tutoren die altijd hoog scoren, dat zowel in productieve als in niet-productieve groepen doen. ${ }^{5}$ Zij kunnen problemen in de groepen aan. Op dit moment wordt verder onderzoek gedaan naar dit fenomeen. Een mogelijke uitkomst van dit onderzoek zou kunnen zijn dat niet iedereen zonder meer geschikt is voor de rol wan tutor. Selectie en/of extra training van tutoren wordt dan de toekomst.

Ook blijken er nog andere factoren mee te spelen. Een paar weken geleden heeft de studentenfractie - op verzoek - klachten van studenten over tutoren geinventariseerd. Ik geef u een korte subjectieve bloemlezing hieruit. De tutor:

wordt steeds weggepiept;

laat zich vervangen door verschillende docenten, die niets weten van het blok;

leest de Observant;

weigert cen patient met psoriasis een hand te geven:

steh voor om de onderwijsgroep niet door te laten gaan en wel af te tekenen;

komt niet opdagen.

Uiteraard zijn dit incidenten, en het zijn ook subjectieve gegevens. Maar het geeft wel an dat er stafleden zijn die merkwaardige opvattingen hebben over het invullen van hun rol in het onderwijs voor aanstaande jonge collegae. As wij docenten zien als rolmodel, zijn dit toch nixt de normen en warden die wij willen overdragen. Als wij woor kwaliteit gaan - en ik dacht dat we dat doen - kunnen we dit niet langer accepteren. 
In de rol wan utor kun je als docent je inhoudelijke kennis slechts in beperkte mate overdragen. Sommige docenten vinden dat vervelend en zinn wellicht niet zo overtuigd dat er een probleem mel docenten is door het eerste voorbeeld. Laten we een voorbeeld bespreken war de docent een meer klassieke docentenrol verwult.

Colleges zijin - zoals u weet - in ons onderwijssysteem een onderwijsvorm die beperkt en selectief wordt toegepast. Je zou dan ook mogen verwachien dat er goede docenten worden geselecteerd, die goede colleges geven. Onderzoek gaf te zien dat 6\% van de lezingen lager dan een 6 scoorde en dat dit bij een groot gedeelte al enkele jaren zo was. De gemiddelde leerzamheid was 6.8 (SD 0.7), $6 \mathrm{k}$ hoop dat u het met mij eens kunt zijn dat, gezien het selectieve gebruik van deze onderwijsvorm, de lat wat hoger mag liggen. Ik zou hogere gemiddelden verwachten en geen onvoldoendes. De gegevens zijn besproken in de onderwijsoverlegorganen en de blokplanningsgraepen zijn erop gewezen dat er meer aandacht aan de kwaliteit van colleges besteed zou moeten worden. In een a antal blokplanningsgroepen is dit advies serieus ganomen. Leden van blokplanningsgroepen wonen colleges bij en geven directe feedback aan de docenten.

Een laatste voorbeeld van gegevens uit de programma-evaluatie. In ellke evaluatie wordt aan studenten gevraagd om te schatten hoeveel zij gestudeerd hebben. De schattingen van studenten komen overeen met getallen die via tijdschrijfonderzoek worden verzameld. ${ }^{7}$ Het blijkt dat het aantal uren dat per blok wordt gestudeerd, sterk varieent. ${ }^{4}$ Er is een blok waar niet meer dan waalf uur per week wordt gestudeerd. Maar er zijn ook blokken waar dertig uur per week wordt gestudeerd. Het kan dus wel: Variabelen die bij de gevonden varschillen een rol spelen, zijn het onderwerp van het blok, vormgeving en opbouw van het blok en de periode van het jaar. Overigens moet opgemerkt worden dat het haalbare aantal studie-uren ook beinvloed wordt door het teit dat veel studenten moeten werken naast de studie vanwege alle bezuingingen op de studiefinanciering.

In de faculteit heeft een tijdje lang de mening geleefd dat door een strenger toetssysteem het aantal studie-uren wel omhoog zou gaan. Uit de grote variatie tussen blokken moet geconcludeerd worden dat het probleem iets complexer is. Het lijkt logisch om te veronderstellen dat 
zowel het onderwijs als hel toetssysteem toe is aan verandering, maar daarover later meer.

Samenwattend, levert programma-evaluatie heel veel wardevolle gegevens. Het is mijns inziens zo dat wij in hel verleden deze gegevens niet altijd optimaal hebben gebruikt. Dus dat moel anders in de Maastrichtse Onderwijs Benadering. Wij gaan voor kwaliteit. Er zijn ook veel positieve gegevens, maar omdat het gaat over mogelijke verbeteringen, heb ik voorbeelden gegeven van onderwijs dat beter zou moeten kumnen.

\section{ONDERZOEKSBEVINDINGEN}

In onze faculteit wordt veel onderzoek van onderwijs gedaan. Dit lijkt voor degenen die de onderwijspraktijk niet zo goed kennen, wellicht vanzelisprekend. Hellas moet ik hen telleurstellen. Op de meeste faculteiten geneeskunde zijn geen of slechts zeer beperkte middelen beschikbaar voor onderzoek van onderwijs en bij ons houdt het ook niet over.

Ik zal eerst enkele vergelijkende studies bespreken en daarna een paar lokale Maastrichtse onderzoeken. In verschillende studies is aangetoond dat er, wat betreft het kennisniveau dat studenten bereiken, geen verschil is tussen faculteiten met een traditioneel curriculum en faculteiten war vernieuwingen zijn doongevoerd. ${ }^{8} 9$ Omdat wij een geheel andere curriculumopbouw hebben, waren die bevindingen indertijd geruststellend. Ze zijn nog steeds van belang, omdat onze studenten en sommige docenten nog steeds de indruk hebben dat Maastrichtse studenten niets weten. Misschien is dat wel waar, maar ze weten in ieder geval even weinig als studenten aan andere faculteiten. Er is wel verschil gevonden, in het voordeel van het Maastrichtse probleemgestururde curriculum, wat betreft vaardigheden, althans voordat in de andere faculteiten het curriculun werd herzien. Maastrichtse studenten voelen zich beter voorbereid op de co-assistentschappen dan studenten in de 'oude' curricula van Nijmegen en Groningen. 10 Maastrichtse studenten voeren meer vaardigheden uit tijdens de co-assistentschappen dan studenten uil Groningen. 11 Onze studenten hebben ook een hoger beheersingsniveau van waardigheden. ${ }^{12}$ Met een kennis-over-vaardig. hedlentoets kon worden aangetoond dat de verschillen wanaf het tweede 
jaar bestaun. ${ }^{13}$ Oniangs werd ook aangetoond daf deze verschillen bestaan met studenten uit Antwerpen en Gent. ${ }^{14}$

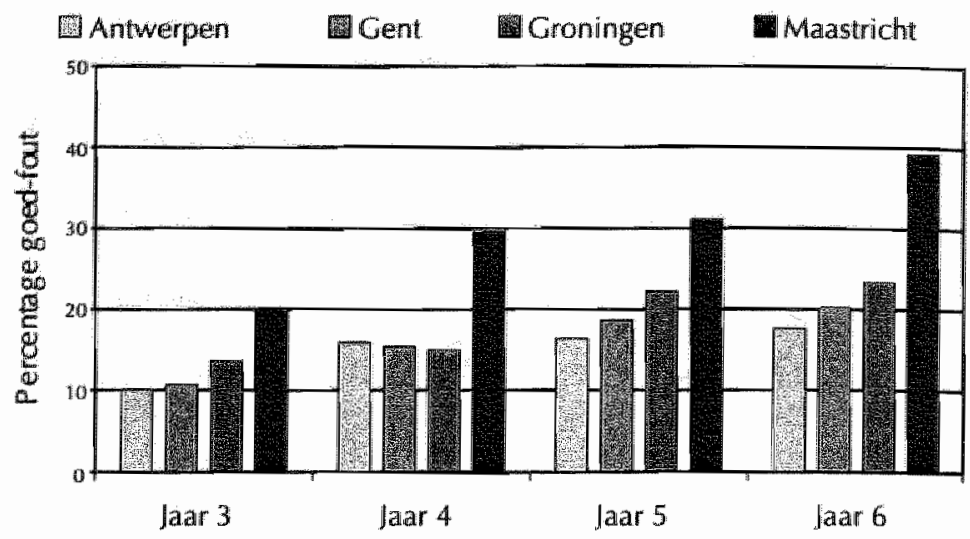

Figuur 1. Scores op een kennis-over-vaardighedentoets van studenten in de latste vier studiejaren in Antwerpen, Gent, Groningen en Maastricht.

In figuur 1 zijn de gegevens weergegeven van de laătste vier studiejaren van de geneeskundeopleidingen in Antwerpen, Gent, Groningen en Maastricht. Ook zijn er verschillen gevonden tussen traditionele curricula en moderne curricula wat betreft probleemoplossingsvaardigheden. 1516 De resultaten zijm allemaal heel positief voor Maastricht, maar de curricula in de andere faculteiten zijn inmiddels veranderd. Hoe zou de vergelijking nu witvallen? Alleen over kennisscores hebber we ook recente gegevens. Toen ik een paar jaar geleden in de oude aula een deel van deze onderzoeksresultaten verdedigde, werd ik door een Groningse opponent uitgedaagd om een "retum match" te spelen. Ik hoefde daar niet lang over na te denken. Mijn antwoord was duidelijk, maar we wachten nog steeds op een uitnodiging. Niet zozeer om aan te tonen wie de beste is, marir omdat we van deze studies veel kunnen leren over de invulling van onze curricula. Hoewel Groningen wat traag is, blifven we niet afwachten. Zo worden op dit moment de gegevens 


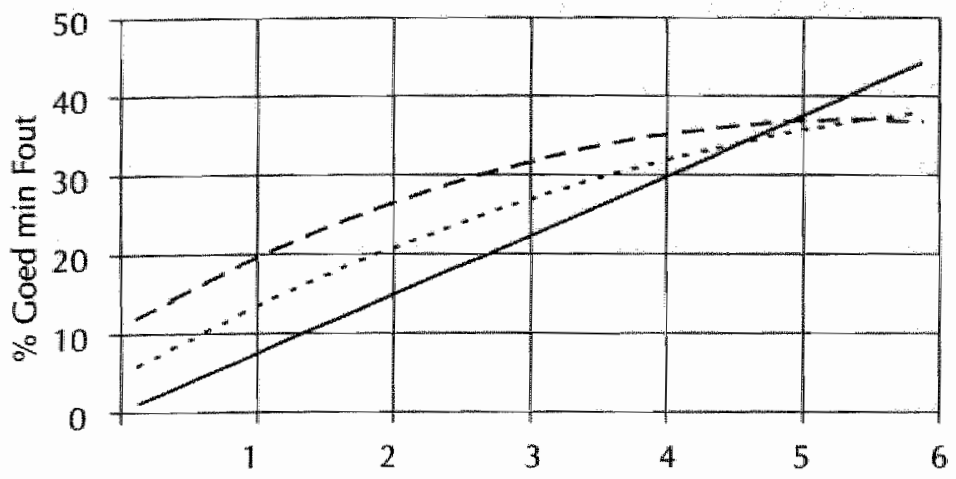

Figuur 2. Scores op de voortgangstoets van jaar 1.6 in de basisvakken (BV), gedragswetenschappelijke vakken (GW) en klinische wakken (KV). De data van 60491 scores gecombineerd.

van een vergelijkende studie naar het niveau van communicatievaardigheden in Leiden en Maastricht geanalyseerd. En binnenkort start een interfacultaire studie naar de kennis van klinisch relevante anatomic.

Er zijn nog een paar recente studies die aanknopingspunten bieden voor verbeteringen. In de eerste aangehaalde interfacultaire studie naar kemnis over vaardigheden blijkt dat de prestaties van de vijfdejaars studenten beneden de verwachting zijn. Er zit als het ware een 'dip' in de groeicurve. Inmiddels is gebleken dat studenten moeite hebben met de overgang van de eerste vier siudiejaren naar de co-assistentschappen. ${ }^{17}$ 18 Het zou kunnen dat het 'leren' hierdoor even wat minder goed gaat. De overgang is ook erg abrupt, wat nooit de bedoeling is geweest van de 'founding fathers' van ons curriculum. De co-assistentschappen zijn nooit echt ander's geweest dan elders. Uit onderzoek blijkt dat er grote variatie is tussen wat co-assistenten zien en dat ze zelden geobserveerd worden en een beperkt aantal patiënten zien. 19.21 Het gegeven dat studenten slechts acht à negen uur per week contact met patiënten hebben. was toch niet helemaal de bedoeling van deze fase ${ }^{21}$ Een 
andere bevinding is dat de groei van kennis van de basisvakken en de gedragswetenschappelijke vakken afwakt vanaf het vierde jaar figutr $21^{22}$ Dit blijkt uit een analyse van 60491 scores op de voortgangstoets wan 3226 studenten.

Samenvattend, zijn er veel positieve onderzoeksresultaten voor Maastricht, maar het betreft vergelijkinger met studenten üt oude, tradi. tionele curriculia. Nu de meeste faculteiten curriculumveranderingen hebben doorgevoerd, is het interessant om oprieuw onderzoek te doen. Daarnaast zijm ar aanwijzingen dat er in jaar vijf en zes veranderingen noodzakelijk zijn. Dat geldt overigens al heel lang en voor heel Nederland. Op een aantal faculteiten word er dan ook hard gewerkt aan herzieningen wan deze fase.

\section{EXTERNE BEOORDELINGEN}

De medische opleidingen worden - zoals vrijwel alle opleidingen gevisiteerd. Tot nu toe hebben twee visitaties plaatsgevonden, waarbij Maastricht goed is beoordeeld. 2324 De visitatiecommissies krijgen van de faculteiten de zelfstudie en hebben de moeilijke taak om in wee dagen meer informatie te verzamelen en te praten met docenten en studenten. Het feit dat de zelfstudies zeer verschillend worden ingevuld en dat de visitatiecommissie slechts met een selectie van docenten en studenten praat, betekent dat de informatie over de individuele faculteiten in het rapport niet zo heel hard' is. De algemene impact wan de visitaties is groot. Zij hebben ongetwijfeld een bijdrage geleverd aan de curriculumherzieningen van de afgelopen jaren. Terecht hebben beide commissies erop gewezen dat er in de faculteiten en universiteiten meer aandacht voor onderwijs en docenten zou moeten komen. De adviezen voor individuele faculteiten moeten mijns inziens met gezond onderwijsverstand geïnterpreteerd worden, waarbij er wel goede argumenten moeten zijn, en bij voorkeur ook 'evidentie', om een aanbeveling niet uit te voeren. Zo is bijvoorbeeld in de eerste visitatie geconstateerd dat wij een mild en kwetsbaar toetsyysteem hadden. Deze uitspraak heeft weel consequenties gehad. Evidentie ontbratk en uit onderzoek is het tegendeel gebleken, zoals u eerder in de voordracht gehoord heeft. Erger nog, in die tijd wisten onze studenten evenveel als studenten elders ên daarbij hadden we ook nog een hoger rendement. 
Twee andere externe beoordelingen, die in de media veel aandacht krigen, zijn de "Keuzegids hoger onderwijs" en De beste studies". 25 . 26 In beide beoordelingen scoort het medisch onderwijs in Maastricht stabiel hoog. Samenvattend zijn de externe beoordelingen van het medisch onderwijs in Maastricht heel positief. Het valt op dat ook andere faculteiten die hun curriculum zïn gaan aanpassen, steeds hoger scoren. Om de positieve beoordelingen te behouden, moeten we mijns inziens zo langzamerhand dus wel wat gaan doen.

\section{COGNITIEVE PSYCHOLOGIE}

Een aantal jaren geleden werd probleemoplossen alls een geïsoleerde vaardigheid beschouwd, die als zodanig geoefend kan worden. Uit cognitief psychologisch onderzoek is gebleken dat deze opvatting niet kllopt. Vaardig probleemoplossen blijkt in thoge mate ahankelijk te zijn vam de inhoud van het probleem. ${ }^{27-29}$ Ook is ontdekt dat er verschillen zijn wat betreft probleemoplossen tussen experts en beginners. Experts kunnen verworwen kennis beter toepassen dan beginners doordat zij in hun geheugen "kennisnetwerken" hebben ontwikkeld die goed toegankelijk zijn. $27-29$ Daardoor is de kennis van experts direct beschilkbaar op het moment dat deze toegepast moet worden. Beginners moeten hun kennisnetwerk nog ontwikkelen. Voor het onderwijs betekent dit dat nieuwe informatie een goede plaats in het 'netwerk-in-ontwikkeling' moet krijgen. Vanuit dit perspectief is probleemgestuurd onderwijs in een kleine groep een geschikte onderwijsvorm. Als het echter in de prakijk van het onderwijs- en toetssysteem toch meer om geisoleerde feiten en vaardigheden gaat, worden er geen goede netwerken aangelegd. De informatie wordt dan niet goed opgeslagen en zal in de praktik dus ook vaak niet teruggevonden kunnen worden. Samengevat: onderwijs dat de nadruk legt op geïsoleerde (feiten)kennis en vaardigheden leidt alleen tot een kortetermijnleereffect en goede resultaten op de betreffende toetsen. Ook is inmiddels bekend dat er geoefend moet worden met de "oude" informatie in de netwerken.27-28 De redenen hiervoor zijn dat door oefenen de informatie beter beklift, de netwerken better gaan functioneren en - als er goede begeleiding is - misconcepties duidelijk worden. Omdat het opslaan en terugzoeken van informatie contextgebonden blijkt te ziph, moet er geoefend worden in verschillende situaties, die 
geleidelijk meer overeenkomen met de werkelijke situatie waarin de student hel probleem moet kumnen oplossen. De context warrin studenten geneeskunde een probleem moeten kumen oplossen is het arts-patiëntcontact. Bij de opbouw van thet curriculum zou dus het arts-patientcontact de rode draad moeten zijn. Aan het begin van thet curriculum moetern er onderwijssituaties gecreëerd worden die lijken op een arts-patiêntcontact en aan het einde van het curriculum functioneert de student als arts. Tussen het begin en het einde komt de student in aanraking met praktijk-en patientenproblemen, die geleidelijk "echter" en ingewikkelder worden. Aan het einde van het curriculum moet de sudent utteraard beschikken over goed functionerende kennisnetwerken. Dat betekent clat arts-patientcontacten met voldoende diepgang moeten worden nabesproken, met aandacht woor pathofysiologie, en in een klimaat waarin misconcepties aan het licht kunnen komen.

Het vertalen wan deze inzichten vergt een heel andere curriculumopbouw dan de algemeen gebruikelijke. De meeste curricula lijken op een (gekantelde) $H$, met een strikte scheiding tussen de eerste vier en de latste twee studiejaren. Over het algemeen zijn er in de eerste vier jaar relatief weinig patiëntencontacten en bestaan de laatste twee jaar vrijwel alleen maar uit praktijkcontacten. In een nieuw curriculum beginnen contacten met patiënten en praktijk van de gezondheidszorg eerder dan in her huidige curriculum. Theoretische concepten en pathofysiologie komen in de latere studiejaren meer aan bod dan nu het geval is. Dit wordt een $Z$-vormig curriculum genoemd. De plannen van de Utrechtse collegae lijken op dit mament het meest op dit toekomstbeeld. ${ }^{30}$ Ook Maastricht heeft inmiddels voor dit model gekozen. ${ }^{31}$ In de curricula van Amsterdam en Nijmegen is de Z-worm ook herkenbaar, maar daar begint de vermenging van theorie en praktijk later in het curriculum. 3233

Samenvattend, komen er uit de programma-evaluatie en uit onderzoek gegevens die aanwijzingen bevatten datt er iets moet veranderen. Enerzijds gaat het daarbij om verbeteringen van kwalliteit en effectiever management, wat terugkomt in de Marastrichtse Onderwijs Benadering. Anderzijds blijkt uit recente inzichten wit de cognitieve psychologie dat het ook gaat om opbouw en inhoud van het curriculum. 
Ik ben nu al een tijdje aan het praten; sommigen in de zaal hebben het zwaar. I heb ook wat negatieve dingen gezegd, die ik overigens van elke faculteit kan vertellen. Wij zijn eerlijk en willen verbeteren. Laten we als intermezzo eens kijken naar een goed stukje ondenwijs. Het zijn beelden van de ongevalssimulatie 'disaster day' in het vijfde blok in jaar vier.

\section{EEN NIEUW CURRICULUM}

Sinds september 1999 is een curriculumherzieningscommissie actief. De commissie bestaat uit: $H$. Crebolder, H. Damen, M. Daemen, G. Dunselman, P. Farla, H. Hillen, B. Kolle, T. Leiner, V. Moulaert, I. Nijhuis, 1. Oosterhof, 1. Rosing, A. Scherpbier, I. Schrander, H. Snellen, 1. Snoeckx, M. Verwijnen, C. van der Vleuten en C. Wesseling. De commissie heeft een aantal uitgangspunten geformuleerd.

- De curriculumherziening is een complete herziening van jaar één tot en met zes. Dat betekent overigens niet dat waardevolle elementen uit het oude curriculum wegvallen. Het gaat erom dat binnen het huidige curriculum de samenhang duidelijk geleden heeft onder slijtage en de aanpassingen van de afgelopen jaren. Een gedeeltelijke vernieuwing kan volgens de commissie niet tot de gewenste verbeteringen leiden.

- Het curriculum duurt zes jaar en wij blijven opleiden tot basisarts. Er is dus geen differentiatie in de betekenis van prespecialisatie. Over beide onderwerpen vinden op dit moment landelijke discussies plaats ${ }^{34} 35$ De commissie is van mening dat dergelijké veranderingen alleen in overleg met de vervolgopleidingen mogelijk zijn, waarbij de consequenties voor het hele continuüm uitgewerkt moeten worden. Dit overleg is inmiddels opgestart, maar het is nog te vroeg om met de uitkomsten rekening te houden.

- Het wordt voor studenten mogelijk om gedurende de opleiding een profiel te kiezen. Dit lijkt wellicht in tegenspraak met het voorgaande. Deze profielen zijn echter zodanig breed dat een basisarts 
na afstuderen nog alle keuzes kan maken. Eén profiel bestat al in hel huidige curriculum, namelijk het zogenaamde onderzoekstraject geneeskunde. Het traject begint in het vierde blok wan het weede studiejaar. De student wordt dan geadopteerd door een onderzoeksgroep en is tot de wetenschapsstage ongeveer een dag per week bezig mer onderzoek, dat daarna in de stage wordt afgerond. Er is inmiddels ook een onderwijstraject geneeskunde ontwikkeld. Andere trajecten zijn in voorbereiding.

- Het curriculum moet stuclentgecentreerd zijn in die zin dat het leren van de student centraal staat. Een variatie aan onderwijsvormen wordt toegepast on dit doel te bereiken.

- Het toetsyysteem wordt opgevat als een onderdeel van het onderwijssysteem. De gekozen instrumenten en de regelgeving moeten zodanig zijn dat het leren van de student wordt ondersteund. De consequentie is dat er ook een variatie aan toetsvormen moet worden ontwikkeld. Uiteraard blift toetsing ook een selectieve functie houden, maar dat is niet meer het hoofddoel.

- De docent moet centraal staan. Hiemee wordt niet bedoeld dat we terug willen nar docentgecentreerd onderwijs. Het is belangrijk dat inspanningen voor onderwijs gewaardeerd worden en de primaire onderwijsrollen, de tutor, de klinisch docent, et cetera, zijn in feite de belangrijkste onderwijsrollen. Dat betekent ook dat er personeelsbeleid zou moeten komen. Beide visitatiecommissies hebben daarover aanbevelingen gedatan. Uiteraard is dit al veel vaker gezegd en het is opmerkelijk dat er maar geen 'schot' zit in het uitwoeren van deze aanbevelingen.

Hoe zien de grote lijnen van het nieme curriculum eruit? We beginnen aan het einde van het curriculum.

- In het zesde jaar is een wetenschapsstage van een half jaar gepland én een praktijkstage van een half jaar. De huidige wetenschapsstage duurt drie maanden en eigenlijk is dat te kort om je als student goed in een onderwerp te kunnen verdiepen. Er is gekozen voor het vertengen wan de stage omdat je een aantal aspecten wan onderzoek alleen leert als je het zelf doet. Gezien de ontwikkeling en organisatie wan het onderzoek, is het logisch om de onderzoeksinstituten een grote rol toe te kennen bij de invulling van deze stages. 
Een van de problemen met de huidige co-assistentschappen is dat studenten overal maar kort zijn. Het is organisaltorisch moeilijk on hun verantwoordelijkheid voor patienten te geven. In een antal stages lukt dat wel, maar zeker niet voor alle studenten. De commissie is van mening dat een student gedurende de opletding moet kunnen leren om verantwoordelijkheid te dragen voor de dagelijkse zorg rondom de patiënt. Alleen op deze wijze kan een groot deel van de algemene eindtermen wit het Raamplan 1994 artsopleiding worden gerealiseerd. ${ }^{36}$ Voorgesteld wordt om daarvoor een half jaar te reserveren. Deze stage kan zowel in het academisch ziekenhuis als in een van de gealfilieerde ziekenhuizen gevolgd worden. Voorwarde is dat de student, onder goede supervisie, verantwoordelijk is woor de dagelijkse zorg rondom de patiënt. Zij moet kunnen oefenen in het functioneren als onderdeel van een team.

- In het vijfde jaar en cen deel van het vierde jaar zijn stages gepland van de disciplines die nu de klassieke co-assistentschappen verzorgen. Alle stages worden georganiseend in de peritere ziekenhuizen, omdat de capaciteit van het academisch ziekenhuis nodig is voor de eerdere studiejaren. Het is de bedoeting dat de stages voornamelijk op de polikliniek plaatswinden, omdat de afgelopen jaren in de zorg een verschuiving heeft plaatsgevonden van kliniek naar polikliniek. Tussen de stages zijn tussenweken gepland, die deels worden ingevuld met rapportages over de opdrachten van het vorige co-assistentschap en deels met voorbereiding op het volgende co-assistentschap. In deze tussenweken is het uitdrukkelijk de bedoeling dat het verband wordt gelegd tussen kliniek en basiswakken. Het stageoverschrijclend onderwijs uit het huidige curriculum wordt in deze weken gegewen. ${ }^{37}$ Om een en ander in de tijd te kunnem realiseren moeten alle co-assistentschappen wat ingekort worden.

- In het derde en een deel wan het vierde studiejaar worden blokken gepland warin theorie en praktijk geintegreerd worden. In deze fase wordt een groot beroep gedaari op de capaciteit van het academisch ziekenhuis. Omdat het onmogelijk is on voor alle studenten tegelijk praktijkcontacten te organiseren, wordt de jaarklasse gesplitsi in klei. 
nere groepen (tracks). De blokken worden het hele jaar gegeven en elke track heeft dus een andere volgorde van blokken. Het nadeel hiervan is dat activiteiten die nu maar éen keer woor de gehele jaarklasse georganiseerd worden, zoals colleges, vaker zullen moeten worden gegeven. Voor kleinschalige activiteiten is er met name een organisatorisch probleem en in feite geen extra belasting voor de docenten. Het grote voordeel is dat met de werkplaats (klinische vakgroepen, huisartsen, et cetera) afspraken gemaakt kunnen worden die het gehele jaar door galden. Hierdoor zijn een effectieve planning en afstemming met de overige taken realiseerbaar. Het overkoepelend thema van de blokken in deze fase is "chronisch zieken'. Een aantal wan de vernieuwingen van de afgelopen jaren, zoals het adoptieprogramma en de hlinische onderwijsgroepen, kunnen - met aanpassingen - getransplanteerd worden. 3939 Nieuwe ontwikkelingen in de zorg, zoals transmurale activiteiten en zorgketens, kunnen eenvoudiger ingevoerd worden in de kleine groepen van de tracks dan woor een gehela jaarklasse.

- In het tweede jaar staat de lewenscyclus - wan bevruchting tot overlijden - centraal. De oriënterende praktijkcontacten variëren van consultatiebureau tot de bejaarde patiënt. Aam het einde van dit studiejaar moeten de studenten zodanige vardigheden bezitten dat zij goed voorbereid zijn op de patientencontacten in het derde studiejaar.

- In het eerste jaar is het vertrekpunt de eerstehulpverlening. Studenten leren de vaardigheden om eerste hulp te verlenen. Nog belangrijker is het concept dat wij vanuit de eerstehulpsituaties de regelsystemen gaan bestuderen. Met in hun hoold thet beeld van de bleke patiënt uit de vaardigheidstraining gaan studenten shock bestuderen.

Dit is het plan in grote lijnen. Het moet werder uitgewerkt worden, maar dat kan alleen samen met de betrokkenen. Als de grote lijnen van ons plan goedgekeurd worden - en daar ga ik van uit - staan wij binnenkort op de stoep om te overleggen over de inwulling. Voor een goede invulling en uitvoering is de Maastrichtse Onderwijs Benadering belangrijk. 
Voor de aamwezigen die tussen alle "druktemakerij" wel eens tijd hebben om televisie te kijken heeft 'the mob' bepaalde associaties. Ahoewel wij door sommigen ook wel eens de onderwijsmaffia zijn genoemd, is het niet de bedoeling om die associatie te benadrukken. Het is ook wel zo geweest in het verleden dat je als onderwijsmens via slinkse wegen je doel moest bereiken. Onderwijs stond niet echt op de agenda. Maat dat is verleden tijd, daar hoeven we het niet meer over te hebben. Onclenwijs staat op de agenda en is geaccepteend als een van de hoofdtaken van de faculteit en de universiteit.

Langzamerhand wordt u misschien nieuwsgierig naar de MOB. Wat is nu die benadering en hoe gaan we dat realiseren? Wat kunt $u$ de komende tijd van ons verwachten? De sleutelwoorden zijn kwaliteit, leiding en management (KLM). Veel onderdelen evvan zijn al aan bod geweest.

\section{KWALITEIT}

De kwaliteit van ons onderwijs moet heel goed zijn. Om te weten of we ook kwaliteit leweren, moeten we goed meten en dus weten wat er precies gebeurt in het curriculum. Het is de bedoeling dat het geplande curriculum zo goed mogelijk overeenkomt met het werkelijke curriculum. ${ }^{40} 41$ Daarvoor hebben we een aantal thulpmiddelen. De meeste informatie over het curriculum hebben de studenten. Gelukkig hebben we in Maastricht een goede studentenorganisatie, namelijk de Studentenfractie. Hun inbreng en betrokkenheid zijn voor ons essentieel. Ook hebben we gegevens nodig via de programma-evaluatie. Die gegevens zijn er eigenlijk al wel, maar we moeten er meer mee doen. We moeten de kwaliteitscyclus geheel doorlopen. ${ }^{2}$ Ook de uitslagen van toetsen leveren informatie over de kwalitelt wan ons onderwijs. Helaas wordien deze gegevens door zowel studenten als docenten onvoldoende gebruikt als intormatiebron over kwaliteit. Om kwaliteit to bereiken moeten we ook onderzoek doen, net als in de patiëntenzorg. De tijd is voorbij dat we alleen op basis wan anze intuitie een kostbare ondenwijsbetiandeling uit konden voeren. Internationall wordt deze trend uilge. 
drukt met het begrip 'best evidence based medical education' ${ }^{43}$ lets minder ambitieus dan evidence based, maar misschien wel realistischer.

\section{LEIDING}

Er moet natuurlijk leiding gegeven worden; de vraag is wadraan en hoe? Als Onderwijsinstituut zijin wij onderdeel van een complexe driehoeksrelatie met studenten en docenten. Ons aller doel is om studenten weel te laten leren. Dat is mijns inziens de belangrijkste reden waaromer een universiteit is. Zonder studenten zaten wij hier niet. Studenten moeten efficiënt en effectief leren en dat gat beter als er een plezierig klimaat is. Dat geldt ook voor docenten, zij moeten efficiënt en effectief, en dus ook prettig werken. Leiding gaat dus niet over macht uitoefenen (o.k., soms moet dat wel eens even), maar over het scheppen van een gunstig leer-en werkklimaat. Leiding betekent ook zorgplicht voor studenten en docenten. Deze visie op leidinggeven betekent een cultuurverandering, we zijn dat niet gewend. Uiteraard kan ik die cultuurverandering alleen namens het Onderwijsinstituut aankondigen. De vraag hoe dat is voor andere bestuurlijke organen kan ik niet beantwoorden.

\section{MANAGEMENT}

Kwaliteit en leiding heeft alles te maken met management. Voor een goed leer- en werkklimaat moet er feedback zijn. Goede docenten en minder goede docenten moeten dat van ons horen. Die feedback moet ook ergens toe leiden. Hetzelfde geldt woor studenten. Het instituut moet informatie verspreiden en die informatie moet leiden tot acties die kwaliteitsverbetering tot gevolg hebben. $U$ kunt van ons verwachten dat er meer acties komen die tot kwaliteitsverbetering leiden. Wij zullen ook preciezer gaan afrekenen, in positieve en in negatieve zin. Goede studenten moeten beloond worden, goede docenten oak en slechte prestaties moeten ook consequenties hebben. Onze gesprekken in de toekomst zullen ook over betaalbaarheid gaan. We moeten gezamenlijk kosten en baten tegen elkaar afwegen, omdat de tijd dat alles kon voorbij is. $U$ moet weten waar het Onderwijsinstituut voor stal. We zullen duidelijk en eerlijk zijn. 
In deze rede heb ik geprobeerd een beeld te schetsen van mijn gedachtem over ondenwijs. Uiteindelijk moeten we voldoen aan de missie van de universiteit. Sleutelwoorden hierin zijn internationalisering en innovatie. De internationalisering heef zich goed ontwikkeld. Innovatief zijn we de latste jaren niet echt meer. Het is mijn stellige overtuiging dat we dat well heel goed kunnen. We hebben een goede basis voor de KLM: goede studenten, goede docenten. Het nieuwe curriculum en de Maastrichtse Onderwijs Benadering zijn haalbaar als we samenwerken. Het Onderwijsinstituut kan dat niet alleen: inbreng van studenten en docenten blijft essentieel. Er is wel een cultuurverandering noodzakelijk in die zin dat de taken onderwijs, onderzoek en patièntenzorg gelijk gewaardeerd moeten worden. Hoewel wij nu instituten hebben, moeten we ons blijven realiseren dat de drie taken een gedeelde verantwoordelijkheid blijven.

Mijn conclusie is dat de sterren goed staan. Met steun van Faculteitsbestuur, Raad van Bestuur (AZM) en College van Besturr worden wij weer innovatief, leveren kwaliteit, zorgen voor studenten en docenten, onderzoeken de effecten van de onderwijstherapie en publiceren erover.

\section{DE VELE ANDEREN}

Aan het einde van deze les moet ik velen bedanken. Alleen kan ik niet zo veel. Gelukkig sta ik voor mijn gevoel hier niet alleen. Ik heb deze functie nooit speciaal geambieerd. Ik ben het Faculteilsbestuur en het College van Bestuur dan ook dankbaar voor het in mij gestelde vertrouwen. Ik reken overigens ook op jullie feedback. Ik wil blijven leren en dat kan nu eenmaal niet zonder feedback.

Studenten zie ik in principe als mijn werkgever, daarnaast als jonge aanstaande collegae. Bovendien zou het zo kunnen zijn dat zij ooit mijn dokter moeten zijn. Dit verklaart in het kort mijn motivatie. Ook van jullie vraag ik feedback.

Een aantal jaren geleden heb ik de transfer gemaakt van Groningen naar Maastricht. Pie Bartholomeus, Arie Nieuwenhuigzen Kruseman en Edward Steur hebben deze Iransfer mogelijk gemaakt. Op het Skillslab heb ik veel voor mij nieuwe vaardigheden kunnen oefenen. De vele goede docenten die daar werken, hebben mij gecoaclht, vertrouwd en 
wan feedback voorzien. Al langere lijd was ik van mening dat dokters zich moeten bezighouden met onderzoek van onderwijs. Een belangrijk argument voor de transfier was dat ik veel dacht té kunnen leren van de collegae van de Vakgroep Onderwijsontwikkeling en Onderwijsresearch. Cees van der Vleuten en de andere $O \& O$-ers, ik leer nog steeds van jullie allen.

Ik heb mij door Vic Bonke laten overtuigen dat er een nieuwe baan voor mij was. Sinds 1 januar 1999 leef $i k$ dan ook een nieuwe werkelijkheid, die zich nog geleidelijk moet vormen, het Onderwijsinstituut In de medewerkers heb ik alle vertrouwen. Hetzelfde geldt voor de sectiehoofden. Paulien Vluggen, Bert Kolle, Maarten Verwifjnen en alle andere medewerkers, samen redien we het wel.

En zo kan ik nog heel lang doorgaan...

Tot slot wil ik mijn vader en moeder en familie en mijn echte vrienden en vriendinnen bedanken voor hun steun en vertrouwen.

Mijn laatste woord is voor mijn kinderen. Ze zijn heel speciaall en niet altijd even makkelijk. Ze lijken dus ook nog op mij en geven erg goedle feedback.

Ik dank u voor uw aandacht. 
1. Scherpbier AJIA. Eerlijk onderwijs (redactioneel). Tijdschrift voor Medisch Onderwijs 2000;19(2):40.

2. Wolthagen HAP. Kwaliteit van klinisch onderwijs lproefschriftl. Maastricht: Datawyse / Universitaire Pers Maastricht; 1993.

3. Dolmans. DHIMA. How students learn in a problem-based curriculum [proefschrift]. Maastricht: Datawyse / Universitaire Pers Maastricht; 1994.

4. Dolmans DHM, Wolthagen HAP. Aandachtspunten programma-evaluatie FdG jaar 1-4 1998-1999. Maastricht: Taakgroep Programma-evaluatie; 1999. BO99-15m431. Intern Rapport.

5. Dolmans DHJM, Wolthagen HAP, Hoogenboom RII, Vleuten CPM van der. Is tutor performance dependent on tutorial groups" productivity? towards further resolving of inconsistencies in tutor pertormance. Teaching and Leaming in Medicine 1999;114:186-91.

6. Dolmans DHIM, Rootselaar AF van, Scherpbier AllA, Snellen-Balendong $H$, Wolthagen HAP. Een inventarisatie van lezingen in thet curriculum van de Faculteit der Geneeskunde. Bulletin Medisch Onderwijs 1995(14):126-9.

7. Jongbloets MWM, Dolmans DHJM, Hoogenboom RJ, Wolfhagen HAP. Het ritme van de tijdsbesteding van de PGO-student. Tijdschrift voor Medisch Onderwijs 2000;19(2):48-55.

8. Verwijnen M, Vleuten CPM van der, Imbos T. A comparison of an innovative medical school with traditional schools: an analysis in the cognitive domain. In: Noomen ZM, Schmidt HG, Ezzat ES, eds. Innovation in medical education: an evaluation of its present status. New York: Springer Publishing Company: 1987. p. 40-9.

9. Verhoeven BH, Verwijnen GM, Scherpbier AllA, Holdrinet RSG, Oeseburg B, Bulte IA, Vleuten CPM van der. An analysis of progress test resuits of PBL and non-PBL students. Med Teach 1998; 20(4): $310-6$. 
10. Busari 1O, Scherpbier AIIA, Boshuizen HPA. Comparative study of medical education as perceived by students at three Dutch universi. ties. Advances in Health Sciences Education 1997; 1:141-51.

11. Scherpbier AllA, Pols I, Nieuwenhuijzen Kruseman AC, Schaper NC, Verwijnen GM, Vleuten CPM van der. Interfacultaire vaardigheidstoets Groningen-Maastricht: eerste resultaten. In: Cate ThI ten, Dikkers IH, Houtkoop E, Pollemans MC, Pols I, Smal IA, eds. Gezond Onderwijs-5. Houten/Diegem: Bohn Stafleu Van Loghum; 1996. p. 351-7.

12.5cherphier AllA. Kwalliteit van vaardigheidsonderwijs gemeten [proefschrift]. Maastricht: Universitaire Pers; 1997.

13. Scherpbier AJA, Verhoeven BH, Bloemen ICM, Cohen-Schatanus I, Pols D, Rossum HIM van, Vleuten CPM van der, Nieuwenhuijzen Kruseman AC. De toename van beheersing van vaardigheden gedurende het curriculum. Een vergelijking tussen Groningen en Maastricht. Bulletin Medisch Onderwijs 1997; 162):101-7.

14. Remmen R. Evaluatie van het vaardigheidsonderwijs aan genees kunde studenten van de Universiteit van Antwerpen iproefschriftl. Antwerpen: Universiteit van Antwerpen; 1999.

15. Schmidt $H G$, Machiels-Bongaerts $M$, Hermans $H$, Cate Tht ten, Venekamp $\mathbb{R}$, Boshuizen HPA. The development of diagnostic competence: comparison of a problem-based, and integrated, and a conventional medical curriculum. Acad Med 1996;716):658-64.

16. Schuwirth LWT, Verhoeven BH, Scherpbier AJA, Mom EMA, Cohen-Schotanus I, Rossum HIM wan, Vleuten CPM van der. An inter-and intra-university comparison with short case-based testing. Adwances in Health Sciences. Education 1999;3:233-44.

17. Wiel MWI van de, Schaper NC, Scherpbier AllA, Vleuten CPM van der, Boshuizen HPA. Students' experiences with real patients tutorials in a problem-based curriculum. Teaching and Learning in Medicine 1999:11(1):12-20.

18. Prince CIAH, Wiel MWJ van de, Scherpbier AIIA, Vleuten CPM wan cler, Boshuizen MPA. De overgang wan theorie naar praktijk in het medisch curriculum. Tijdschrift woor Medisch Onderwijs 2000 (geaccepteerd). 
19. Scherpbier AJJA, Metz JCM. Co-assistentschap: een stage? Bulletin Medisch Onderwijs $1989,812,64-7$.

20. Weg $N$ van de, Visser $K$, Seuren $M$, Scherplyer AJA, Woltenbuttel $\mathrm{BHR}_{a}$ Wolfhagen HAP. TIJdsesteding van comassistenten nader bekeken. Bulletin Medisch Onderwijs 1993;12(4):173-9.

21. Szenas $P$. The role of faculty observation in assessing students clinical skilts. Contemporary Issues in Medical Education 1997;111: $1-2$.

22. Verhoeven BH, Verwijnen GM, Scherpbier AJJA, Vleuten CPM van der. Growth of medical knowledge. Submitted.

23. Vereniging van Samenwerkende Nederlandse Universiteiten. Visitatierapport Geneeskunde en Gezondheidswetenschappen. Utrecht: Vereniging van Samenwerkende Nederlandse Universiteiten; 1992.

24. VSNU-Visitatiecommissie Geneeskunde en Gezondheidswetenschappen. Onderwijsvisitatie geneeskunde en gezondheidswetenschappen. Utrecht: Vereniging van Samenwerkende Nederlandse Universiteiten; 1997.

25. Steenkamp $F$, Maljars $W$, redactie. Keuzegids hoger onderwijs 1999-2000. Amsterdam: Uitgeverij Balans; 1999.

26. De beste studies. Elsevier Special. Oktober 1999.

27. Regehr G. Norman GR. Issues in cognitive psychology: implications for professional education. Acad Med 1996:71(9):988-1001.

28. Schmidt $\mathrm{HG}_{\mathrm{r}}$ Norman GR, Boshuizen HPA. A cognitive perspective on medical expertise: theory and implications. Acad Med $1990,65(10) 611-21$.

29. Boshuizen HPA. De ontwikkeling van medische expertise; implicaties voor het praktisch en theoretisch medisch onderwijs. In: Metz ICM, Scherpbier AJIA, Vleuten CPM van der, redactie. Medisch onderwijs in de praktijk. Assen: Van Gorcum; 1995. p. 25-39.

30. Blauwdruk I nieuw curriculum Utrecht. Utrecht: Opleidingsbestuur; 1998 .

31. Scherpbier AllA, Crebolder H, Essed G, Samen M van, Schaper N, Schrander J, et al. Van papier nar patiënt; gedachten over curriculumverbetering. Interne notitie aan Bestuur Faculteit der Ceneeskunde. Maastricht: Universiteit Maastricht" april 1998. 
32. Cate Thy ten, Damner SA, Lanschot I wan, Büller HA, Michels RP, Krol LI, et al. Ifteriening co-assistentschappen AMC: hoofdlinen van een nieuwe vormgeving. In: Verweil AWIJ, Albersnagel EA, Cate Thl ten, Denekens I, Dikkers $\| H$, Remmen R, et al., redactie. Gezond Onder wijs-7. Houten/ Diegem: Bohn Stafleu Van Loghum; 1998. p. 75-8.

33. Bestuurscommissie Herziening Curficula. Vernieuwing co-assistentschappen. Nümegen: Faculteil der Medische Wetenschappen; 1997.

34. Molenaar J. De goede dokter Ideaalbeeld of vrome wens. Utrecht: Van der Weer; 1999.

35. Lange J) de. Leidt de medische opleiding nog artsen op? Ned Tijdschr Gieneeskd 2000;144(5):232-6.

36. MetzICM, Pels Rijcken-Van Erp Taalman Kip EH, Brand-Valkenburg BWM van den. Raamplan 1994 artsopleiding; eindtermen van de artsopleiding. Nijmegen: Universitair Publikatiebureau Katholieke Universiteit Nijmegen; 1994.

37. Essed GCM, Boshuzen HPA. Stage-overstijgend klinisch onderwijs te Maastricht. Medisch Contact 1993;48:1051-2.

38. Crebolder HFIM, Metsemakers IFM, Op 't Root IMH, Bartholomeus P. Bouhuys P, Boshuizen HPA. Patiëntgebonden onderwijs in de huisartspraktijk binnen de artsopleiding. Het programna van de Rijksuniversiteit Limburg. Ned Tijdschr Geneeskd 1996:140: $1320-3$.

39. Schaper N, Scherpbier AllA, Vles H, Greve WW, Rosing $\downarrow_{\text {, Evers H et }}$ al. Tussen denken en doen. Maastricht: Faculteit der Geneeskunde; 1995 (BO 95-15.249, interne notilie).

40. Nelson M, Jacobs C. Cuban L. Concepts of curriculum leditoriall. Teaching and Learning in Medicine 1992;4:202-5.

41. Coles CR, Grant IG, Curriculum evaluation in medical and health-care education. Med Educ 1985;19:405-22.

43. Harden RM, Grant I, Buckley G, Hart IR. BEME guide no. 1: best evidence medical education. Med Teach 1999;21(6):553-62. 